\title{
Teaching NeuroImage: Symmetric Deep Cerebellar White Matter T2 and Susceptibility-Weighted Imaging Hypointense Lesions in a Case of Cerebrotendinous Xanthomatosis
}

Yue Zhang, MD, PhD, * Yi-Min Sun, MD, PhD,* and Haiqing Li, MD, PhD

Neurology ${ }^{\circledR}$ 2021;97:e968-e969. doi:10.1212/WNL.0000000000012154

Figure Clinical, Imaging, and Magnetic Resonance Spectroscopy (MRS) Findings
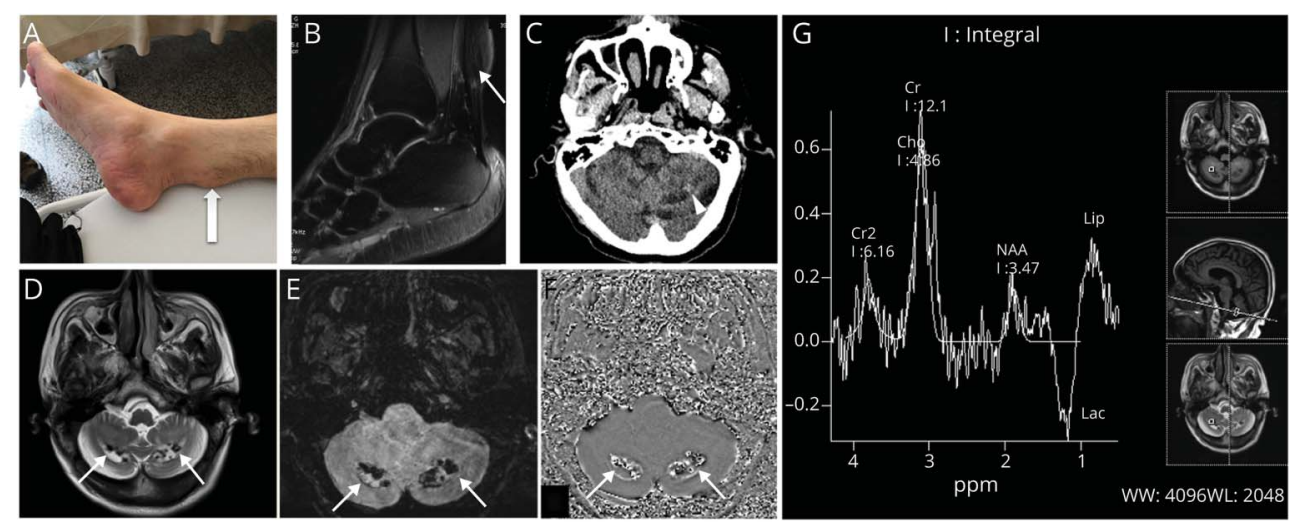

(A, B) Enlargement of Achilles tendon. (C) Brain CT shows modest hyperdensity in cerebellar hypodense lesions. (D) T2-weighted imaging reveals hyperintensity with spots of hypointensity, which were more evident on susceptibilityweighted imaging (E, F). (G) MRS demonstrates decrease in N-acetylaspartate (NAA) and increase in lipid (Lip) and lactate (Lac) peaks.

A 39-year-old man presented with worsening slurred speech, difficulty walking, and falls for 2 years. Examination found severe ataxia and enlargement of Achilles tendons. Brain CT demonstrated modest hyperdensity in cerebellar hypodense lesions. T2-weighted imaging revealed hypointensity in deep cerebellar white matter, more evident on susceptibility-weighted imaging. Magnetic resonance spectroscopy suggested lipid storage and mitochondrial dysfunction. The diagnosis of cerebrotendinous xanthomatosis (CTX) was confirmed by gene screening of CYP27A1 (Figure).

The typical imaging finding of CTX is T2-weighted imaging hyperintensity in dentate nucleus. Cerebellar hypointensity is occasionally seen in the late stage and indicates deposition of hemosiderin and microhemorrhages, ${ }^{1}$ which may be secondary to cerebellar vacuolation. $^{2}$

\section{Study Funding}

The authors report no targeted funding.
Correspondence

Dr. Li

lihaiqing@fudan.edu.cn

\section{MORE ONLINE}

Teaching slides

links.lww.com/WNL/ B408

*These authors contributed equally.

From the Departments of Neurology (Y.Z., Y.-M. Sun) and Radiology (H.L.), Huashan Hospital, Fudan University, Shanghai, China.

Go to Neurology.org/N for full disclosures. Funding information and disclosures deemed relevant by the authors, if any, are provided at the end of the article. 


\section{Disclosure}

The authors report no disclosures relevant to the manuscript. Go to Neurology.org/N for full disclosures.

\section{Appendix Authors}

\begin{tabular}{lll}
\hline Name & Location & Contribution \\
\hline $\begin{array}{l}\text { Yue } \\
\text { Zhang, } \\
\text { MD, PhD }\end{array}$ & $\begin{array}{l}\text { Department of Neurology, } \\
\text { University, Shanghai, China }\end{array}$ & $\begin{array}{l}\text { Patient management, } \\
\text { analysis of the radiologic } \\
\text { data, preparation of the } \\
\text { draft manuscript }\end{array}$ \\
\hline $\begin{array}{l}\text { Yi-Min } \\
\text { Sun, MD, } \\
\text { PhD }\end{array}$ & $\begin{array}{l}\text { Department of Neurology, } \\
\text { University, Shanghai, China }\end{array}$ & $\begin{array}{l}\text { Critical review of } \\
\text { manuscript, language } \\
\text { modification }\end{array}$ \\
\hline
\end{tabular}

Appendix (continued)

Name Location Contribution

Haiqing Department of Radiology,

Li, MD, Huashan Hospital, Fudan

PhD University, Shanghai, China

Concept and design of the study, analysis of the radiologic data, critical review, final approval of the manuscript to be published

\section{References}

1. Barkhof F, Verrips A, Wesseling P, et al. Cerebrotendinous xanthomatosis: the spectrum of imaging findings and the correlation with neuropathologic findings. Radiology. 2000;217(3):869-876.

2. Mignarri A, Dotti MT, Federico A, et al. The spectrum of magnetic resonance findings in cerebrotendinous xanthomatosis: redefinition and evidence of new markers of disease progression. J Neurol. 2017;264(5):862-874. 


\section{Neurology}

\section{Teaching NeuroImage: Symmetric Deep Cerebellar White Matter T2 and Susceptibility-Weighted Imaging Hypointense Lesions in a Case of Cerebrotendinous Xanthomatosis}

Yue Zhang, Yi-Min Sun and Haiqing Li

Neurology 2021;97;e968-e969 Published Online before print May 4, 2021

DOI 10.1212/WNL.0000000000012154

This information is current as of May 4, 2021

\section{Updated Information \&} Services

References

Subspecialty Collections

Permissions \& Licensing

Reprints including high resolution figures, can be found at: http://n.neurology.org/content/97/9/e968.full

This article cites 2 articles, 0 of which you can access for free at: http://n.neurology.org/content/97/9/e968.full\#ref-list-1

This article, along with others on similar topics, appears in the following collection(s):

MRI

http://n.neurology.org/cgi/collection/mri

Information about reproducing this article in parts (figures,tables) or in its entirety can be found online at:

http://www.neurology.org/about/about_the_journal\#permissions

Information about ordering reprints can be found online:

http://n.neurology.org/subscribers/advertise

Neurology ${ }^{\circledR}$ is the official journal of the American Academy of Neurology. Published continuously since 1951, it is now a weekly with 48 issues per year. Copyright () 2021 American Academy of Neurology. All rights reserved. Print ISSN: 0028-3878. Online ISSN: 1526-632X.

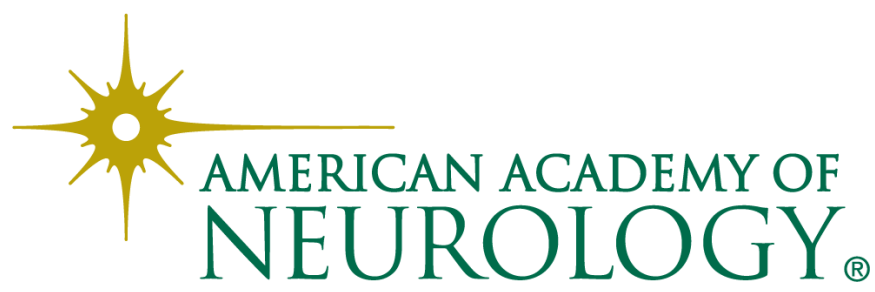

